\title{
Primary osteosarcoma of the thyroid gland: report of a rare neoplasm
}

Osteossarcoma primário da glândula tireoide: relato de uma neoplasia rara

Eduardo Cambruzzi ${ }^{1}$; João Grigoleti Scholl²; Alberto Salgueiro Molinari³; Karla Lais Pêgas ${ }^{4}$

\begin{abstract}
Primary mesenchymal tumors of the thyroid gland are extremely rare. The authors report a case of primary thyroid osteosarcoma in a male patient presenting a tumoral mass in the neck. CT scan demonstrated a large tumor in the right thyroid lobe with areas of calcification. The surgical specimen consisted of a hard brown-gray tumor, measuring $13 \times 11 \times 7.5 \mathrm{~cm}$. Microscopy revealed a high-grade malignant neoplasm composed of polygonal cells of intermediate size, chondroid pattern in some areas and osteoid formation. The process was immunonegative for AE1/AE3, glial fibrillary acidic protein (GFAP), epithelial membrane antigen (EMA), p53 and thyroid transcription factor-1 (TTF-1), and immunopositive for CD99 and S100. Thus the diagnosis of primary osteosarcoma of the thyroid gland was established.
\end{abstract}

Key words: osteosarcoma; thyroid gland; pathology; immunohistochemistry.

\section{INTRODUCTION}

The annual incidence of thyroid cancer ranges from 0.5 to 10 cases per 100,000 inhabitants, representing the most common malignancy of the endocrine system ${ }^{(2)}$. Thyroid tumors account for $1 \%$ of the overall human cancer burden, and papillary carcinoma is the most frequent histological type ${ }^{(2,7)}$. Thyroid cancer occurs primarily in young and middle aged patients. Furthermore, they are $2-4$ times more frequent in women than in men ${ }^{(2,7)}$. The vast majority of thyroid carcinomas are indolent malignancies with a ten- year survival rate in over $90 \%$ of the cases ${ }^{(2,7,11)}$.

Primary mesenchymal tumors of the thyroid are extremely rare and sarcomas of different types have been described in this site ${ }^{(1-3)}$. In general, thyroid sarcomas have been associated with a poor prognosis and occur mainly in the elderly ${ }^{(1-3)}$. Herein, the authors report a new case of primary osteosarcoma of the thyroid gland (POT) and review histopathological findings, diagnostic criteria and therapeutic management of this uncommon tumor.

\section{CASE REPORT}

A 69-year-old male patient came to hospital service presenting with a mass in the neck. At physical examination, a large, firm, solid tumor in the anterior cervical region was found. The patient had no prior history of malignancy. CT and ultrasound demonstrated a large mass in the right thyroid lobe, with extensive areas of calcification, measuring $10 \mathrm{~cm}$ in the large dimension. Radiological and CT scans of the chest and larynx did not identify significant changes. Fine-needle aspiration was performed and showed rare pleomorphic atypical cells. The intraoperative frozen biopsy identified a high grade malignant neoplasm with osteoid areas. The surgical specimen consisted of a bosselated, brown, hard tumoral lesion, weighing $447 \mathrm{~g}$ and measuring $13 \times 11 \times 7.5 \mathrm{~cm}$. The process had a brown-gray, lobulated cut surface with areas of necrosis and calcification and a peripheral zone of chondroid appearance (Figure 1). Microscopy revealed a high-grade malignant neoplasm composed of polygonal cells of intermediate size and hyperchromatic nucleus (Figure 2) presenting high mitotic index and necrotic areas. A chondroid pattern, osteoid formation and thin bone anastomosing trabeculae were identified in some areas. Numerous osteoclast-like giant cells were present in small zones. The process revealed negative immunoexpression for AE1/AE3, glial fibrillary acidic protein (GFAP), epithelial membrane antigen (EMA), p53 and thyroid transcription factor-1 (TTF-1), and positive immunostaining for CD99 and S100. The clinical and imaging findings associated with the histological and immunohistochemical features enabled the diagnosis of high grade primary osteosarcoma of the thyroid gland. The patient was referred for radiotherapy, and after two months of follow-up, showed no clinical evidence of local recurrence or systemic involvement.

First submission on 15/08/12; last submission on 29/12/12; accepted for publication on 30/12/12; published on 20/02/13

1. Post-doctorate in Cardiovascular Pathology by Instituto de Cardiologia do Rio Grande do Sul; professor at Universidade Luterana do Brasil (Ulbra); pathologist.

2. Pathologist at Hospital Nossa Senhora da Conceição-RS.

3. Master's in Endocrine Surgery by Universidade Federal do Rio Grande do Sul (UFRGS); surgeon at Hospital Nossa Senhora da Conceição-RS.

4. Master's in Pathology by Fundação Universidade Federal de Ciências da Saúde de Porto Alegre; pathologist at Santa Casa de Porto Alegre. 


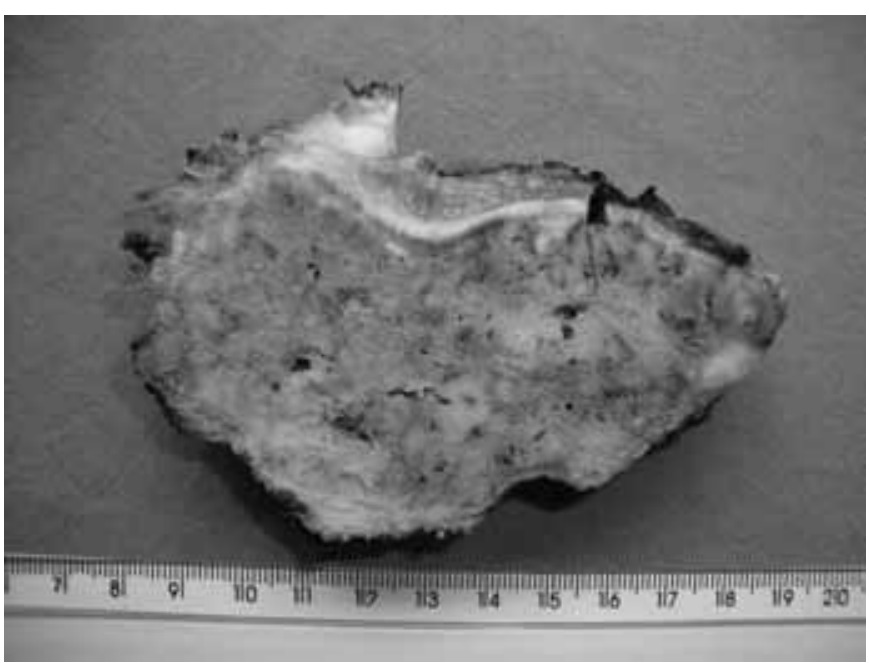

FIGURE 1 - Primary thyroid osteosarcoma: a dense, solid neoplasm with a lobulated cut surface and chondroblastic peripheral areas
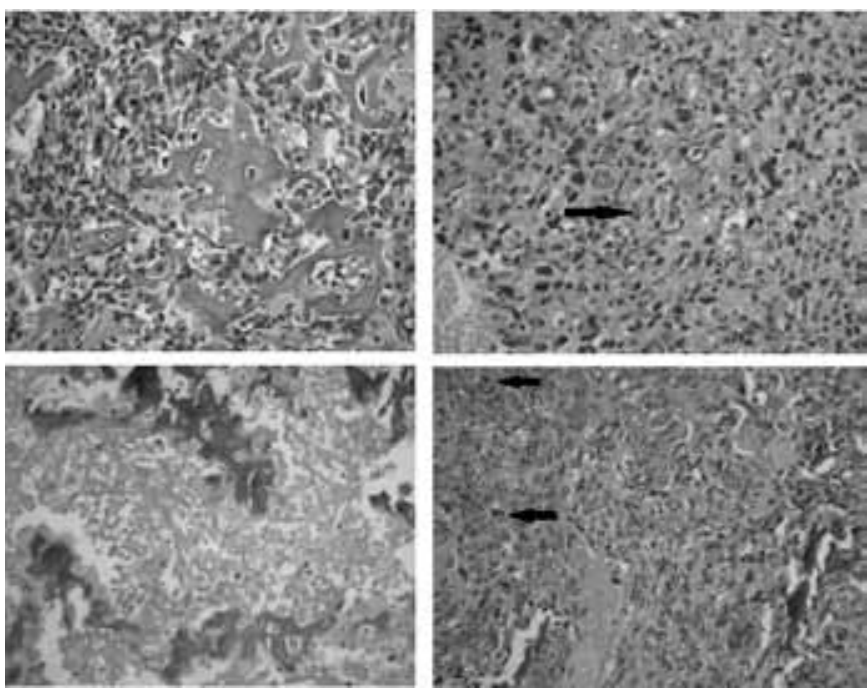

FIGURE 2 - Primary thyroid osteosarcoma: a high grade malignant tumor exbibiting hypercellularity, pleomorphic cells around osteoid production, atypical mitosis (arrows), and foci of necrosis, $H E, 100 \times$

HE: hematoxylin and eosin.

\section{DISCUSSION}

Primary mesenchymal tumors of the thyroid gland are exceedingly rare. Most of them are represented by cases of angiosarcoma, leiomyoma, leiomyosarcoma, schwannoma, and paraganglioma ${ }^{(1,2,6)}$. Approximately 30 cases of POT gland are described in the literature ${ }^{(1,2,6)}$.
Almost all patients with POT present with a rapidly expanding, single neck lesion. Cervical pain, dysphagia, dyspnea, edema, and vocal cord paralysis may be important associated symptoms ${ }^{(1,2,4,6)}$. POT varies in size from $1.5 \mathrm{~cm}$ to large masses. The lesions are usually grey-tan and sharply demarcated, and its consistency varies from firm to stony hard ${ }^{(1,2,4-6)}$. POT is a high grade pleomorphic malignance in which the neoplastic cells recapitulate the phenotype of osteoblasts and produce osteoid, without morphological or immunohistochemical evidences of epithelial differentiation. Histologically, osteoid is a dense, pink, amorphous intercellular material, which may appear somewhat refractile ${ }^{(2,3,7-9)}$. POT may also contain cellular elements that differentiate along chondroblastic and fibroblastic cell lines. The tumor tends to be a highly anaplastic lesion in which the neoplastic cells may be epithelioid, fusiform, ovoid, small round cells or even multinucleated giant cells ${ }^{(2,3,7-9)}$. Areas of necrosis and a high mitotic index are common findings. Osteosarcomas usually have diffuse moderate to strong intra-cytoplasmic staining for CD99. Osteocalcin and osteonectin may be used to highlight osteoid $^{(2,3,7-7,10)}$.

The differential diagnosis includes metastatic lesions, secondary tumors arising in the larynx, and undifferentiated thyroid (anaplastic) carcinomas (UTC) $)^{(1-3,5-7,71)}$. UTC are highly malignant tumors that appear wholly or partially composed of undifferentiated cells that exhibit immunohistochemical or ultrastructural evidences of epithelial differentiation. Most UTC are widely invasive tumors that comprise an admixture of spindle cells, pleomorphic giant cells and epithelioid cells. Extensive coagulative necrosis and occasional giant cells are often detected. Tumors predominantly or exclusively made up of spindle cells often present a sarcomatoid appearance and may resemble fibrosarcoma, leiomyosarcoma or occasionally an angiosarcoma ${ }^{(2,3,5-7,11)}$. The osteoclastic variants of UTC are uncommon lesions that are characterized by the presence of a large number of multinucleated, non-neoplastic-like giant cells. In most cases, UTC revealed positive immunoexpression for AE1/ AE3 and EMA, and negative immunostaining for thyroglobulin. Occasionally, UTC revealed positive staining for carcinoembryonic antigen (CEA) and TTF-1 ${ }^{(2,3,5-7,11)}$.

The ideal treatment for POT seems to be that indicated for the conventional cases of primary skeletal osteosarcoma due to its aggressive local growth and possible haematogenous dissemination $\left.{ }^{2}, 3,5,7,9\right)$. Prognostic factors are related primarily to the extent of the disease at presentation. Predictive factors associated with histomorphological and genetic features of POT have not been described ${ }^{(2,3,5,7)}$. In the actual report, after a short clinical follow-up of six months, there were no signs of recurrence or distant metastasis, although the present case corresponded to a bulky, high-grade malignancy.

Herein, the authors describe a case of osteosarcoma arising in the right lobe of the thyroid gland in a 69 year-old male patient. In general, osteosarcomas are high grade neoplasms arising in the femur and tibia of young patients. In the absence of prior history of usual osseous osteosarcoma or clinical evidences of laryngeal sarcoma, associated with immunohistochemistry evaluation, the diagnosis of POT may be considered. 


\section{RESUMO}

Tumores mesenquimais da glândula tireoide são extremamente raros. Os autores relatam um caso de osteossarcoma primário de tireoide em um paciente masculino que apresentou massa tumoral na região cervical. A tomografia computadorizada demonstrou um grande tumor no lobo tireoideano direito, com zonas de calcificação. A peça cirúrgica consistia de um tumor marrom-acinzentado e firme, medindo $13 \times 11 \times 7,5 \mathrm{~cm}$. À microscopia, foi encontrada neoplasia maligna de alto grau composta por células poligonais de tamanbo intermédio, com um padrão condroide em algumas áreas e formação de osteoide. O processo revelou imunoexpressão negativa para AE1/AE3, proteina glial fibrilar ácida (GFAP), antígeno da membrana epitelial (EMA), p53 e fator de transcrição da tireoide (TTF-1) e imunopositividade para CD99 e S100. 0 diagnóstico de osteossarcoma primário da glândula tireoide foi, então, estabelecido.

Unitermos: osteossarcoma; glândula tireoide; patologia; imuno-histoquímica.

\section{REFERENCES}

1. ADAPA, P.; CHUNG, T. W.; POPEK, E. J.; HUNTER, J. V. Extraosseous ewing sarcoma of the thyroid gland. Pediatr Radiol, v. 39, n. 12, p. 1365-8, 2009.

2. DE LELLIS, R. A.; LLOYD, R. V.; HEITZ, P. U.; ENG, C. Tumors of the thyroid and parathyroid. In: DE LELLIS, R. A. et al. (Eds.). Tumors of endocrine organs - pathology \& genetics. World Health Organization Classification of Tumors. Lyon: IARC Press, 2004. p. 49-80.

3. HERTEL, V.; BASTEN, 0.; BOCKMÜHL, U. Extraosseous osteosarcoma of the thyroid gland. Layngorbinootologie, v. 85, n. 12, p. 913-6, 2006.

4. LIVINGSTONE, D. J.; SANDISON, A. T. Osteogenic sarcoma of thyroid. $\mathrm{Br} J$ Surg, v. 50, p. 291-3, 1962.

5. LUNA-ORTIZ, K.; ORTEGA-GUTIERREZ, C.; DOMINGUEZ-MALAGON, H.; MOSQUEDA-TAYLOR, A. Extraosseous osteosarcoma in the neck. Auris Nasus Larynx, v. 39, n. 3, p. 333-6, 2012.
6. MAKIS, W.; NOVALES-DIAZ, J. A.; HICKESON, M. Primary thyroid osteosarcoma: staging and evaluation of response to therapy with F-18 FDG PET-CT. Clin Nucl Med, v. 35, n. 7, p. 517-20, 2010.

7. MIETTINEM, M.; FRANSILA, K. 0. Variable expression of keratins and nearly uniform lack of thyroid transcription factor 1 in thyroid anaplastic carcinoma. Hum Pathol, v. 31, p. 1139-45, 2000.

8. NITZSCHE, E. U.; SEEGER, L. L.; KLOSA, B.; FREUDENBERG, N.; MOSER, E. A. Primary osteosarcoma of the thyroid gland. J Nucl Med, v. 33, n. 7, p. 13991401, 1992.

9. STROHSCHNEIDER, T.; WIRTH, W.; HOLZWARTH, M.; TIMM, D. Primary osteosarcoma of the thyroid gland. Zentralbl Chir, v. 124, n. 9, p. 840-2, 1999. 10. SYRJÄNEN, K.J. Fine needle aspiration cytology of the thyroid osteosarcoma. Report of a case.J Cancer Res Clin Ocol, v. 96, n. 3, p. 319-23, 1980.

11. TONG, S. X.; HAMELE-BENA, D.; LIU, J. C.; HORST, B.; REMOTTI, F. Fineneedle aspiration biopsy of primary osteosarcoma of the thyroid: report of a case and review of the literature. Diagn Cytopathol, v. 36, n. 8, p. 589-94, 2008.

\section{MAILING ADDRESS}

Eduardo Cambruzzi

Hospital N. Sra. Conceição; Laboratório de Patologia; Av. Francisco Trein, 596, $2^{\circ}$ andar; CEP: 91350-200 - Cristo Redentor; Porto Alegre-RS, Brazil; Tel.: (51) 3357-2164; e-mail: dudacambruzzi@yahoo.com.br. 